\title{
Comparative Civil Procedure and the Style of Complex Contracts
}

\author{
John H. Langbein*
}

Among businessmen and lawyers familiar with commercial practice in complex transactions on both sides of the Atlantic, it is a common observation that a contract drafted in the United States is typically vastly more detailed than a contract originating in Germany or elsewhere on the Continent. My purpose in this paper is to inquire into the causes of that notable difference in the style of contracting.

The Belgian legal writer Georges van Hecke discussed this subject in a stimulating paper that is now a quarter-century old. He illustrated the phenomenon with an anecdote. $\mathrm{He}$ told of a transaction in which an American company and a European company were planning to affiliate by exchanging shares. The lawyers for the American firm drafted two contracts to embrace the transaction. The combined drafts ran about 10,000 words in length. The European businessman had no prior experience with American lawyers, and when presented with the elephantine American drafts he was so shocked that he nearly renounced the deal. Thereupon it was decided to start over, and the European businessman arranged for his lawyer to prepare a counterdraft. "The result was a document of 1400 words. It was found by the American party to include all the substance that was really needed, and it was readily executed by both parties and adequately performed." 1

\section{VAN HECKE'S ACCOUNT}

Why are American contracts so much more detailed than Euro-

* Max Pam Professor of American and Foreign Law, University of Chicago Law School. The author wishes to thank Douglas Baird, James Beardsley, Dennis Carlton, Gerhard Casper, George Crawford, Richard Epstein, Mary Ann Glendon, Hein Koetz, John Merryman, Richard Posner, Erich Schanze, and Diane Wood for helpful comments on a former draft.

This article results from a paper presented to the International Symposium on the Complex Long-Term Contract, held at Heidelberg University in October 1986. I wish to express my gratitude to the conference organizer, Professor Fritz Nicklisch, whose efforts made this forum possible.

1. Van Hecke, "A Civilian Looks at the Common-Law Lawyer," Intermational Contracts: Choice of Law and Language 5, 10 (Parker School of Foreign and Comparative Law, Columbia University, ed. 1962). 
pean? ${ }^{2}$ Van Hecke's article supplies a convenient starting point for that inquiry. He offered three explanations.

1. Perfectionism. Van Hecke attributed to the American lawyer a drive "for perfection that is not commonly to be found in Europe. The average American businessman is prepared to pay for this perfection in the form of high fees," while his European counterpart is not." But why? Why does "[t]he average European businessman" seem to think "that a perfectly watertight contract cannot be achieved and that it is not worthwhile to pay unreasonably high fees for an objective that is not within reach"?" To speak of differing prospensities for perfectionism merely restates the problem, which is to understand why the Americans strive for contractual terms that are, in van Hecke's apt phrase, "perfectly watertight".

2. Federalism. Van Hecke directed attention to the multiplicity of American jurisdictions. "An American lawyer, when drafting a contract, does not know in what jurisdiction litigation will arise. He must make a contract that will achieve its purpose in any American jurisdiction." By contrast, the European lawyer "always has in mind the law of one country where the contract is being localized by both choice of law and choice of forum."6

I think this argument is considerably overstated. European states are comparatively small, and European deals must frequently entail multistate dimensions. Further, the degree of diversity among the American states in matters of contract and commercial law is relatively slight-certainly less than among the states of Europe. Although there are 50-odd American jurisdictions, all but Louisiana and Puerto Rico have a law of contracts based on English common law; and all except Louisiana now adhere to the Uniform Commercial Code for commercial transactions. ${ }^{7}$

I do concede the point at which van Hecke hints when he speaks of choice of law. The movements that have dominated

2. At some level the tension between "going short" and "going long"-between capturing the essentials and enumerating the details-is endemic to legal drafting in any legal system. Nor is the choice confined to styles of contracting; it can be seen in statutory drafting as well. Contrast the gargantuan and pedantic Prussian civil code of 1794 with the compressed and reticulated civil code (the BGB) that emerged on the same soil a century later. Or notice the difference in aspiration between the American antitrust statutes (the Sherman and Clayton acts) that "went short", on the one hand, and the pension law (ERISA) that "went long". The point being asserted in text is not that Europeans always "go short," but that Americans are comparatively more disposed than Europeans to "go long".

3. Id. at 11 .

4. Id.

5. Id.

6. Id.

7. National Conference of Commissioners on Uniform State Laws, 1985-1986 Reference Book 105 (1985). Louisiana has enacted portions of the U.C.C. 
American choice-of-law thinking in recent decades have materially impaired the predictability of our conflicts rules. Yet, if the sponginess of American conflicts law were the factor driving American lawyers to particularize the terms of complex contracts, we would expect to see Americans drafting skimpier, more European-style documents in real estate contracts, trust instruments, and other fields where choice-of-law problems are slight or can be easily avoided. As a trust lawyer, I assure you that such is not the case. Gargantuan, massively detailed instruments are a hallmark of routine trust drafting.

3. Code law versus case law. The most intriguing of van Hecke's suggestions is that the different American style of contracting is a manifestation of that seemingly profound difference between Continental and Anglo-American legal systems: The European private law is codified whereas the American is not. Codification, especially in Germany and in the German-influenced legal systems, entailed not only a reorganization of the law, but a scientific recasting of legal concepts. "The European lawyer has at his command a store of synthetic concepts, such as 'force majeure' [an odd example, since equivalent notions exist in the common law]. Their exact meaning may not always be perfectly clear, but they do save a lot of space-consuming enumeration."8 By contrast, American lawyers draft to combat "the lawless science of their law, that codeless myriad of precedent, that wilderness of single instances." Thus, van Hecke observes, "when a European and an American lawyer want to express the same thing, an American lawyer needs far more words." 10 American contracts are prolix because American substantive law is primitive.

The way to test this beguiling notion is to ask whether it fairly describes what the American draftsman is doing with his boilerplate. Is he really using his instrument to compensate for the lesser precision of his substantive law? Van Hecke supplies a single (and not very typical) example of American boilerplate-he found it in a contract and could not resist quoting it. The term read: "Except where otherwise indicated by the context, singular terminology shall indicate the plural and neuter terminology shall include the masculine and feminine." 11 Van Hecke then remarked dryly: "I do not know in what American jurisdiction such a clause is considered to be necessary. ..."12 The answer, of course, is that it is not necessary in any

8. Id.

9. Id. at 6, quoting, at n. 5, Lord Macmillan, who did not identify the source. It is Tennyson, Aylmer's Field 146 (1894 ed.). I owe this reference to Hein Koetz.

10. Id. at 10 .

11. Id.

12. Id. 
American jurisdiction, but neither do Continental codes contain such drivel. Whatever may be the purpose of such a clause, it hardly seems to have much to do with that "store of synthetic concepts"13 that distinguish the best codes.

I do not mean to deny the bearing that the gulf between caselaw and code-law legal cultures may have on the contrast between American- and Continental-style contracting. I would agree to reckon this difference in legal cultures as a predisposing factor. American lawyers, reared in the case method, may indeed be more sensitive to the nuances of factual detail than Continental lawyers, whose training emphasizes doctrinal principles. Sometimes American boilerplate can be traced to a particular decided case, whose result the draftsman is trying to avoid. But comparative law long ago recognized how much case law was being generated in the code systems, indeed, how strongly the forces of convergence were narrowing the code law/case law contrast. Accordingly, it seems unrealistic to attribute a practical difference as fundamental as the discrepancy between American- and Continental-style contracting to that tired contrast between code law and case law.

\section{The OBJects of Prolixity}

Broadly speaking, the provisions that lengthen most American contracts serve either of two purposes.

1. Transaction-specific foresight clauses. Van Hecke ascribed to perfectionism the American lawyer's effort to "handle all eventualities in the contract rather than leave them to the decision of the judge."14 Much of the detail in an American contract is tailored to the particular transaction, and is designed to foresee ever more remote contingencies. But human foresight has major limits, as anyone who follows the stock market will attest. Today's price changes reflect failures of foresight by half of yesterday's traders. Since it is so intrinsically difficult to foresee future turns of events, the question is why the Americans bother. Why should Americans be so much more reluctant than Europeans to leave future events "to the decision of the judge"?

2. Incorporating default rules. Even more curious than the striving of the American draftsman to foresee the unforeseeable is his propensity for incorporating into a contract numerous well-settled principles of law ("black letter rules") and canons of interpretation (such as van Hecke's illustration about construing number and gender). To be sure, some boilerplate varies the subsidiary law, but most boilerplate imposes rules whose applicability should be easily

13. Id.

14. Id. at 11 . 
ascertainable if not instantly obvious. In current legal-academic parlance, these are "default rules"-the rules that would routinely apply if the contract had neglected to govern the matter. The puzzle about American practice is to understand why, when the default rules are obvious, the draftsman nevertheless wants to internalize them in the instrument.

Notice that neither the foresight clauses nor the clauses incorporating default rules have much to do with the relative merits of American and European substantive law. As regards foresight clauses, the arguably superior Continental substantive law has no advantage. The limits of foresight arise from the human condition; European lawyers do no better at prophecy than American. The question is why the Americans strain so much harder against the limits of foresight. When, on the other hand, the contract is incorporating a default rule, the relative sophistication of the rule is beside the point. The rule would govern, whatever its quality. The phenomenon that needs explaining is why Americans put the rule in the deal for the offchance that it is needed, rather than leave it on the statute book or in the case law.

\section{Procedure AND Procedural Institutions}

I wish to offer a suggestion about the causes of American-style contracting that points away from substantive law and toward procedure. I locate the problem in another of the grand contrasts of comparative law: not code law versus case law, but in the gulf between Continental and American civil procedure and procedural institutions.

If you are a businessman (or the legal advisor to a businessman) and you are contemplating a complex transaction, one of your decisions is how much time, effort, and money you want to invest in contracting precisely. To be sure, the clarity of the underlying substantive law will strongly affect your decision, but as I have said, there is little reason to think that American law is so consistently and markedly underdeveloped by comparison with the law in all the European states that differences in the quality of the substantive law could explain the differing propensities of American and European businessmen to invest in contracting precisely.

Far more important, in my view, is your perception of the efficiency and predictability of the procedural system through which you would have to work in order to vindicate your substantive rights. The point is not that most deals breed lawsuits-in truth few do-but that, ex ante, every complex written contract contemplates the risk of a lawsuit in the event of a breach. If the procedural system that would process such a lawsuit is reasonably efficient, you 
will have less to fear from litigation than if it is not. For reasons that I shall summarize below, American civil procedure is inefficient. It is expensive, protracted, and unpredictable, and it does a poor job of discouraging frivolous suits (or frivolous defenses). The European systems are markedly more efficient and more predictable (some, to be sure, more so than others).

A businessman aware that his transaction would be subject to litigation under the American system would have a materially greater incentive to invest in contracting precision. His object would be to prevent the lawsuit, by foreseeing the claim and stipulating against it; or, should litigation nevertheless arise, to reduce the range and complexity of the issues.

Consider, therefore, some of the most prominent shortcomings of American civil procedure:

1. Who decides. Recall van Hecke's formulation of our problem: "[T]he American lawyer tries to handle all eventualities in the contract rather than to leave them to the decision of the judge."15 Then recall who judges in American courts. The bench is composed of politically selected (sometimes politically elected) ex-lawyers, as opposed to the career magistrates who staff European courts. The range of quality within the American judiciary is notoriously broad, especially in the state courts that handle most commercial business. The best American judges are splendid figures, but what must concern a transaction planner is the risk that his contract will fall to a judge drawn from the bottom of the American deck. A prudent transaction planner assumes the reasonable worst case, and in the United States in a matter of potential litigation that means reckoning on a judge of the meanest ability and disposition.

Contrast in this regard the litigation prospects of the European businessman. If his contract should give rise to litigation, the matter will be decided by a trustworthy career judiciary whose members have been selected and promoted on criteria of ability, learning, and diligence. If the case cannot be clarified and resolved by settlement, the first instance court decides the dispute by means of a written judgment containing findings of fact and rulings of law. ${ }^{\mathbf{1 6}}$

The conclusory general verdict of an American jury is, by contrast, the antithesis of a reasoned judgment; nor does American procedure require much better when the judge decides without a jury. ${ }^{17}$

15. Id.

16. I have recently discussed these contrasts in Continental and American procedure, court structure, and judicial staffing in Langbein, "The German Advantage in Civil Procedure," 52 Univ. Chi. L. Rev. 823, 848-57 (1985).

17. I continue to speak of the reasonable worst case, which is the transaction planner's standard. A particular lawsuit might fare better. In place of the general verdict, the judge might ailow a special verdict, in which the jury is asked "written 
The failure of American procedure to require effective disclosure of the grounds of decision at first instance greatly hampers appellate review.

The European transaction planner knows that if he is dissatisfied with the first-instance decision, he can obtain review de novo (that is, full retrial on all issues of fact and law, with no presumption of correctness attaching to the first-instance decision). ${ }^{18}$ The reviewing court will be composed of seasoned judges who have been promoted to the appellate bench in recognition of the quality of their performance in lower-court adjudication. Particularly in commercial matters, it is common for European legal systems to employ specialized courts or divisions, sometimes even at first-instance, and routinely at the appellate level. ${ }^{19}$ Thus, on the Continent, a complex transaction that results in litigation will be decided by people who are expert in the law governing such affairs-a notable contrast to the amateurs who populate the American generalist judiciary.

And, of course, the grotesque amateurism of the American civil jury system will not bedevil the European businessman. It is conceivable that there is merit in having laymen adjudicate civil cases that partake of ordinary experience; but no prudent businessman would want to delegate to randomly selected laymen the power to pass upon complex commercial and technological questions. Historically, the law/fact distinction (reinforced by the reductionism of common law pleading) limited jurors to deciding issues of "mere" fact. In today's circumstances, however, issues of fact can be vastly more difficult than those of law. If a legal system puts unsophisticated laymen in charge of deciding issues of advanced finance and technology, transaction planners will strain to avoid litigating in that legal system.

2. Trial: adversary distortions. American procedure can function with a bench of uncertain quality in part because the judicial role is narrower. In the American adversary system, the lawyers for the parties gather evidence in advance of trial with virtually no judicial involvement. The lawyers also dominate American trial proce-

questions susceptible of categorical [i.e., yes or no] or other brief answer. . ." Federal Rules of Civil Procedure, Rule 49(a) (1983 ed.). A special verdict is better than a general verdict but hardly a substitute for the full and reasoned disclosure of an experienced decisionmaker. In juryless cases the judge is supposed to make findings of fact, e.g., id., Rule 52(a), but these findings are often perfunctory. See, e.g., Leubsdorf, "Constitutional Civil Procedure," 63 Tex. L. Rev. 579, 630 \& n.311 (1984).

18. For comparative discussion, see Kaplan, von Mehren \& Schaefer, "Phases of German Civil Procedure," 71 Harv. L. Rev. 1193, 1443-54 (1958).

19. For the German scheme of specialized commercial chambers at first instance, see Gerichtsverfassungsgesetz $\S \S 93-114$. For an instructive comparative account of the German specialized appellate chambers, see Meador, "Appellate Subject Matter Organization: The German Design from an American Perspective," 5 Hastings Int' $l$ \& Comp. L. Rev. 27 (1981). 
dure. Each side decides what evidence to present and in what sequence. Continental procedure lacks the pretrial/trial distinction, and the judge has the primary responsibility for eliciting the facts.

The truth-defeating excesses of American trial practice are well known: coaching of witnesses, abusive cross-examination, and the use of party-selected, litigation-biased experts. ${ }^{20}$ Civil procedure in a system like the German quite effectively prevents these abuses. Because the lawyers are forbidden to have pretrial contact with nonparty witnesses, trial testimony is undistorted. The judge does most of the examining of witnesses at trial, which largely eliminates partisanship and trickery in examination and cross-examination. Perhaps most important for the businessman concerned about the possibility that a complex commercial transaction might give rise to litigation, the German court has the help of neutral experts chosen for their ability to assist the court in deciding correctly, rather than (as in American practice) hirelings selected for their willingness to reach preordained results favorable to the adversaries who hired them. ${ }^{21}$

From the standpoint of the transaction planner, these truth-defeating excesses of American procedure all trend in the same direction: They reduce the predictability of litigation by increasing the chance that adversary trickery will wrest an advantage over orderly disclosure and consideration of relevant information.

3. Runaway pretrial. A corollary of the principle of the concentrated trial that dominates American civil procedure is that there must be a separate pretrial process for the parties to gather the evidence that they may need at trial..$^{22}$ The judge customarily has little contact with this pretrial investigation, although, especially in large multi-party litigation, the prototype of strict judicial passivity is softening. ${ }^{23}$ The parties' lawyers employ the compulsory powers of the discovery system largely without judicial supervision. They gather documents from each other, and they create fresh evidence by propounding interrogatories and by deposing witnesses.

This system is immensely expensive and wasteful. It suffers

20. These themes are developed in Langbein, supra n. 16 at $833-41$.

21. For discussion of the German practice, see id. at 835-41. French practice differs materially, but not in the critical respect that experts are capable and impartial. See Beardsley, "Proof of Fact in French Civil Procedure," $34 \mathrm{Am}$. J. Comp. L. 459, 484-85 (1986).

22. For an illuminating discussion of the central role of the principle of the concentrated trial in the Anglo-American procedural tradition, see von Mehren, "The Significance for Procedural Practice and Theory of the Concentrated Trial: Comparative Remarks," in 2 Europäisches Rechtsdenken in Geschichte und Gegenwart: Festschrift für Helmut Coing 361-71 (Horn ed. 1982).

23. See, e.g., Resnik, "Managerial Judges," 96 Harv. L. Rev. 376 (1982). See generally, "Symposium on Litigation Management," 53 Univ. Chi. L. Rev. 305-560 (1986). 
two fundamental flaws. It is intrinsically duplicative: Witnesses are prepared, examined, and cross-examined during pretrial, then prepared, examined, and cross-examined again at trial. But worse, the want of judicial direction of pretrial all but guarantees that discovery proceedings will be overbroad. In any legal system, a lawsuit arising from a complex transaction can have many endings. Only rarely can a litigator tell at the beginning precisely what issues and what facts will prove important in the end. In a legal system such as the German, the judge controls what issues will be investigated and in what sequence. He limits the fact-gathering to the most promising issues-those most likely to clarify the case and hence to promote settlement or adjudication. ${ }^{24}$ Much of what could be investigated does not have to be. By contrast, the American pretrial/trial division requires ${ }^{25}$ that discovery take place for the entire case before the trier has the opportunity to signal what information he thinks relevant to the decision. American lawyers thus strain to investigate everything that could possibly arise at trial, because once the trial commences there is no opportunity to go back and search for further information.

The basic incentives of the American discovery system make for waste and duplication. Discovery is the main activity of the American litigator. An experienced American transaction planner knows that a central risk of having his contract enmeshed in litigation is having to pay for so much legal makework.

4. Costs: subsidizing losers. Unique among the legal systems of the world's advanced states, American civil procedure lacks the general principle that the loser pays the winner's legal expenses. ${ }^{26}$ The world's most expensive legal system is also the least sensitive about allocating the cost burden in a fair and rational manner. While not all the ramifications of the American no-cost-shifting rule trend in the same direction, ${ }^{27}$ the most important consequence of the American rule is to encourage contumacy. In a loser-pays system, the party with a bleak or hopeless case has a strong incentive to

24. For comparative discussion of the German practice see Langbein, supra n. 16 at $826-30$.

25. Since 1980, phased discovery has been authorized under Federal Rules of Civil Procedure, Rule 26(f), and some judges do exercise their authority to direct discovery, especially in complex multi-party litigation. But the transaction planner has no guarantee that his case will be handled by such a managerial judge; and if managerial judging mangles the pretrial, there is almost no appellate safeguard. See Resnik, supra n. 23 at 378,380 .

26. Recently canvassed in the Symposium, "Attorney Fee Shifting," 47 L. \& Contemp.Prob. 1-354 (1984); see especially Pfennigstorf, "The European Experience with Fee Shifting," id. at 37.

27. See Posner, Economic Analysis of Law 538-40 (3d ed. 1986); Shavell, "Suit, Settlement, and Trial: A Theoretical Analysis under Alternative Methods for the Allocation of Legal Costs," 11 J. Leg. Stud. 55 (1982). 
foresake or abandon litigation. Under the American rule, by contrast, litigating a losing case can be a strategic way of inflicting costs on the other side. The American transaction planner knows that if he has to litigate to enforce his deal, he cannot be made whole. 5. The planner's response. I have assembled this catalogue of procedural horrors with a view to showing why a rational businessman should be terrified of having to litigate about a complex contract ${ }^{28}$ under the American civil procedural system. Unfortunately, it is very hard to contract out of a procedural system entirely. Two contracting parties located, say, in Pennsylvania would have a hard time under the applicable choice-of-law rule ${ }^{29}$ devising an enforceable term that litigation arising under the contract should be processed in Germany. Nor would they want to. There are enormous difficulties and costs associated with litigating offshore: the inconvenience and expense of a distant forum, the translations across language and culture, the limits of foreign writ in such matters as compulsory process and execution of judgment. Reasons such as these explain why, even when an American firm engages in a transnational transaction that could plausibly invoke foreign law and a foreign forum, the American firm will often seek to impose American law. Convenience and familiarity supply formidable economies.

The much-heralded growth of arbitration and of other modes of alternative dispute resolution (ADR) in American commercial practice is, of course, consistent with the thesis I have been advancing in this paper. ADR represents another kind of contractual response to the defects of ordinary civil justice. Whereas contracting precision aims to foresee the problems, ADR tries to avoid the courts. If anything, the puzzle is to understand why Americans do not make greater use of arbitration clauses than is now common. I sense that the American lawyer does not fully trust arbitration agreements, at least not enough to surrender his boilerplate. He may fear that the court that adjudicates his contract will prove hostile to arbitrationthat the court will dust off the old theory that arbitration offends

28. Similar concerns about dysfunction in civil procedure and judicial administration trouble the transaction planner who is trying to effect a gratuitous transfer, for example, a will, and the response has been similar. In circumstances in which it would be malpractice for an American lawyer to delete the usual boilerplate (i.e., provisions waiving bond, imposing personal representatives, minimizing judicial approval of accounts, preventing the guardianship of minors' property, and so forth), a German lawyer might confidently recommend a will of a few sentences. See, e.g., the form for the so-called Berliner Testament in Beck'sches Formularbuch zum Bürgerlichen Handels- und Wirtschaftsrecht 643-44 (Hoffman-Becking \& Schippel, eds. $3 d$ ed. 1984).

29. See, e.g., 1 American Law Institute, Restatement of the Law: Conflicts of Law (Second) § 80, at 244-45 (1971). 
public policy because it ousts the jurisdiction of the courts; ${ }^{30}$ or that, despite a good deal of contrary legislation and decisional law restricting judicial review of arbitration awards, a reviewing court may still find a way to subvert the award. ${ }^{31}$

Because it is so hard for the American transaction planner to escape the shortcomings of his legal system, he is left to concentrate on contracting precision for the purpose of narrowing his exposure to the system. This motivation is clearest in those provisions that I have called transaction-specific foresight clauses. To quote van Hecke's formulation yet again, "the American lawyer tries to handle all eventualities in the contract rather than leave them to the decision of the judge." 32

The other great source of prolixity in American-style contracting-general boilerplate incorporating the law that should apply even without the contractual term-is also to be explained by fear of the litigation system. Why trust a judicial lightweight to find his way in the law to the right rule when you can impose it on him in the contract? Why should you risk a jury trial and its attendant pretrial abuses over the question of whether you meant for some ordinary principle of commercial or legal common sense to apply? The instinctive response is to spell it all out. Remember in this regard that, unlike transaction-specific clauses, ${ }^{33}$ general boilerplate is cheap to use. Formbooks collect the stuff, and businesses and law firms tend to develop and carry forward their own sets of it. Boilerplate becomes habit-the mos Americanus.

30. For a recent example, see Wells v. Mobile County Board of Realtors, Inc., 387 So.2d 140, 144-45 (Ala. 1980).

31. "[C]ourts are requiring, to an increasing degree, not only that the entire arbitration be fair but appear to be fair." Sweeney, "Judicial Review of Arbitral Proceedings," 5 Fordham Int'l. L. J. 253, 276 (1981-82)(emphasis original).

Arbitration is not the only plausible escape from the legal system. Because contracting and vertical integration are alternative modes of arranging business, vertical integration should be more attractive as contracting becomes less advantageous. Implicitly, therefore, Americans should be more disposed to vertical integration than the Europeans. But that proposition is hard to test, because so many other factors bear on the levels of vertical integration.

32. Van Hecke, supra n. 1 at 11.

33. The smaller the deal, the more likely is the American lawyer to overcome his instinct for contracting precision. The client will not pay $\$ 20,000$ for legal services to implement a $\$ 10,000$ deal. American and Continental contracting styles diverge least in the realm of the small deal, for which an exchange of relatively simple letters would be as nearly as routine on one side of the Atlantic as on the other.

An experienced American draftsman has remarked to me that he senses a difference in the predilection for contracting precision according to whether his client is an independent entrepreneur or a large corporation. Corporate officers are more likely to want to "cover themselves," to show superiors that the attempt was made to "think of everything".

Another wise practioner has mentioned to me the bureaucratic factor. In large American law firms, many hands will touch a draft, and each draftsman wants to make and preserve his own contribution. 
To be sure, the effort at greater precision in contracting is sometimes counterproductive. Detail is not synonymous with certainty. Because the risks of ambiguity and of missed connections increase with the complexity of an instrument, the draftsman may breed litigation where he meant to prevent it. Alas, American practice seems to show that the draftsman will respond by producing yet more boilerplate for the next contract, hoping for the future to cover the contingency that surprised him the last time.

\section{WHITHER ENGLAND?}

The astute van Hecke noticed an important point about American-style contracting: The English do not much practice it. "I heard recently from a lawyer for an American enterprise engaged in business in several European countries and in the United Kingdom," van Hecke wrote. "He said that American drafts meet with about as great resistance on account of their length, in England as on the Continent."34 I, too, have heard such reports, from English and American lawyers. In general, English-drafted contracts run longer than European drafts but far shorter than American ones. American-style contracting is an Americanism, not an Anglo-Americanism.

In matters having to do with comparative civil procedure, we expect to see England aligned with the United States. American lawyers never tire of exulting in the ancient English heritage of their legal system. American Bar Association politicians love to deck themselves in the pomp of English judicial ritual. Indeed, the president of the ABA shows up each fall at the ceremonial opening of the English courts, where he gets to prance around with the ermine-clad and bewigged figures, seemingly from a distant age, who lend a soothing dignity to the American lawyer's shoddy litigation racket.

The question that naturally arises is this: Can we attribute American-style contracting to the influence of the procedural system when the English, who also practice adversary civil procedure, do not share American contracting prolixity? The answer is straightforward and instructive. Despite the shared precepts of the adversary system, American and English procedure diverge sharply in those fundamental respects in which American practice is so alarming.

Although drawn from the bar and hence not career magistrates, English judges are selected and promoted strictly on criteria of juridical merit. ${ }^{35}$ Civil jury trial for commercial transactions has been

34. Id.

35. See, e.g., Jackson, The Machinery of Justice in England 469-70 (7th ed. 1977). In "[t]he English system," write James and Hazard, "selection of judges [is made] by 
abolished. ${ }^{36}$ The trial judge adjudicates by means of a reasoned opinion that discloses his findings of fact and rulings of law, thereby enhancing the litigant's safeguard in appellate review. The English pretrial discovery system is materially less adventurous than the American, ${ }^{37}$ and users are subject to a cost sanction that-by charging the moving party for makework-helps deter abuse. Punitive damages have been largely suppressed. Adversary distortion at trial is more modulated. The barrister/solicitor division, although hardly praiseworthy, does have the advantage of restraining pretrial coaching of witnesses. Partisan experts are less mischievous when set loose on an experienced and elite bench than when allowed to beguile jurors or hack judges. And perhaps most important, English law applies the loser-pays cost-shifting norm, which greatly deters nuisance litigation and promotes settlement. ${ }^{38}$

Thus, what ails American civil procedure, and what Americanstyle contracting has arisen to avoid, is less the adversary principle than the many mistakes Americans have made in implementing it.

\section{BEyond PROCEDURE}

In emphasizing the shortcomings of American civil procedure and procedural institutions as the primary explanation for American-style contracting, I do not mean to exclude other factors. Indeed, I think a considerable list of such factors could be assembled. There is, for example, no real American counterpart to the Continental general clauses. In Germany, $\S 242$ of the BGB has been interpreted as having written into every contract a judicially supervisable requirement of good faith, far more wide-ranging than the equivalent notions in the American Uniform Commercial Code. Accordingly, the German contract draftsman may feel that he cannot keep the courts out. Excessive detail may look like over-reaching and invite judicial suspicion. I do not mean to convey any particularly high regard for the expansive jurisprudence of $\S 242$. I share with John Dawson ${ }^{39}$ the American lawyer's suspicion that the parties to a contract are likely to know more about the conventions

an essentially nonpolitical authority from among the trial bar (barristers) on the basis of professional assessment of merit as evidenced by experience in practice." James \& Hazard. Civil Procedure $\S 6.7$, at 299 (3d ed. 1985). See also Shetreet, Judges on Trial: A Study of the Appointment and Accountability of the English Judiciary 46-84 (1976).

36. Jackson, supra n. 35 at 84-86, 498-500.

37. See generally, Levine, Discovery: A Comparison Between English and American Civil Discovery Laws with Reform Proposals (1982). For a capsule statement of the differences, see id. at 8-9.

38. Jackson, supra n. 35 at 518-21.

39. See Dawson, "Judicial Revision of Frustrated Contracts: Germany," 63 Boston U. L. Rev. 1039, 1085-88, 1095-98 (1983). 
of their trade than a judge, even a German judge. My point is simply that if transaction planners understand that they cannot forestall judicial oversight, they will not waste words trying.

American-style contracting is related to the broader use of lawyers throughout American business. In areas as diverse as taxation, regulatory compliance, and transaction planning, European businessmen are more likely than Americans to act without counsel. Some of this greater lawyerization of American life simply recapitulates my theme (preventive law is the reaction to deficient legal procedures and institutions), but the phenomenon is surely deeper.

Another suggestion that I find plausible although hardly cogent is that cultural differences in the conduct of commercial affairs play a role in American-style contracting. Business in the United States has not been the preserve of the gentle elite. Commercial dealings in Europe may have been conducted within a smaller and more socially homogeneous group, and hence may have had more of the considerate overtones that Americans think are confined to long-term (that is, relational or repeat-player) contracts.

I have no doubt that a much longer list of such possibilities can be assembled. I doubt, however, that anything on that list will explain as much about the difference in the style of complex contracts as does comparative civil procedure. 